\title{
LICE I NALIČJE BAŠTINE: PRILOG RASPRAVI O POJMU TEŠKE BAŠTINE
}

DOI: $10.17234 /$ SEC.31.9

Prethodno priopćenje

Primljeno: 15. 7. 2019.

Prihvaćeno: 29. 11. 2019.

\author{
HELENA STUBLIĆ \\ Filozofski fakultet Sveučilišta u Zagrebu \\ Odsjek za informacijske i komunikacijske znanosti \\ Ivana Lučića 3, \\ HR - 10000 Zagreb, Hrvatska \\ hstublic@ffzg.hr \\ iD orcid.org/0000-0001-7699-189X
}

\begin{abstract}
Ovaj rad nalazi se u otvorenom pristupu i može se distribuirati u skladu s odredbama licencije CC BY-NC-ND 4.0 HR
\end{abstract}

Rad pruža uvid u problematiku pojmova baština i teška baština. Dublje istraživanje izvora i upotrebe ovih pojmova ima za svrhu rasvjetljavanje pozicija koje se zauzimaju njihovim korištenjem te reperkusija koje iz toga proizlaze. Teška baština pojam je kojim se mahom označavaju baštinski fenomeni koji su u sukobu sa službenim narativima i kulturnim politikama. U radu se iznose tri primjera teške baštine - iz Berlina, Zagreba i Busana - koji će poslužiti kao osnova za analizu pojmova. Rad će prikazati kolika je opravdanost upotrebe distinktivnog pojma teške baštine te koje su njegove prednosti i nedostaci kada se upotrebljava unutar znanstvenog diskursa.

Ključne riječi: baština, teška baština, interpretacija, autorizirani baštinski diskurs, muzealizacijski paradoks, muzeologija, nacizam, antifašizam

"I did that" says my memory.

"I couldn't have done that" - says my pride, and stands its ground. Finally, memory gives in. (F. Nietzsche, Beyond Good and Evil)

\section{UVOD}

Ovim će se radom istražiti i prezentirati višeznačnost pojmova baština i teška baština te kompleksnost koja proizlazi iz njihove raznolike upotrebe. Kako bismo u cijelosti razumjeli razloge koji su doveli do oblikovanja pojma teške baštine, a koji je sve češće u upotrebi u stručnoj i znanstvenoj literaturi, nužno je istražiti semantička svojstva 
pojma baština te njegovu pojavnost u nekoliko velikih europskih jezika. U prvom dijelu rada stoga se komparativnom analizom uspoređuje pojam baštine i srodni pojmovi. Interpretacija baštine važan je segment brojnih znanstvenih disciplina koji zahtijeva visoku razinu razumijevanja baštinskih fenomena, konteksta u kojem su nastali, ali i onog u kojem se trenutačno nalaze te koja je njihova svrha za budućnost. Interpretacija je inherentno ideološka i u tom smislu treba biti svjestan reperkusija upotrebe pojma teška baština. Drugi dio rada donosi pregled dostupne relevantne literature koja spominje neki oblik teške baštine primjenjujući različite pojmove i pojašnjenja. Četvrti dio ukratko prezentira tri primjera (teške) baštine, iz Njemačke, Hrvatske i Južne Koreje sa svrhom ilustracije različitih konteksta i okolnosti u kojima neki aspekt baštine biva označen kao teška baština. Svi navedeni primjeri dijele mnoge sličnost, ali i razlike te se njihovom analizom nastoji utvrditi opravdanost upotrebe zajedničkog nazivnika teška baština. U petom dijelu rada analiziraju se karakteristike pojma teške baštine te se propituje njegova svrha i motiv upotrebe. Pojam teške baštine koristi se pod pogrešnom pretpostavkom da je općepoznato njegovo značenje i da je segment baštine koji pokriva nešto sasvim blisko i samorazumljivo. Nizom argumenata i primjera bit će prikazana višedimenzionalnost ove teme, a krajnji cilj rada jest osvijestiti kompleksnost teme teške baštine te postaviti temelje za daljnja istraživanja i diskusiju.

\section{O DEFINICIJI I ZNAČENJU POJMA BAŠTINA}

Kako bismo mogli definirati pojam teške baštine (engl. difficult heritage), odnosno utvrditi koje je njegovo značenje, a slijedom toga položaj u teorijskom okviru muzeološke interpretacije baštine, potrebno je prvo podrobno promotriti upotrebu pojma baština. Pojam baština u hrvatskom jeziku prema Hrvatskom jezičnom portalu definiran je kao: ${ }^{1}$

(1) imanje koje je naslijeđeno, baštinjeno; bašćina, djedovina, očevina

(2) arh. a. dobro, imanje; b. njiva, livada; c. zavičaj, postojbina

(3) ukupnost iz prošlosti sačuvanih i njegovanih kulturnih dobara [nacionalna baština]; baštinstvo, naslijeđe. ${ }^{2}$

Iz navedenoga je vidljivo da se pojam baština u prvom redu vezuje uz materijalno naslijeđe ili imovinu. No, treće ovdje navedeno značenje ono je koje nas posebno zanima, a upućuje na prošireno značenje pojma i uvelike globalno uvriježeno kao kulturna baština. Ona dakako ne mora biti samo kulturna, materijalna ili nacionalna,

\footnotetext{
1 Ista definicija može se pronaći i u Velikom rječniku hrvatskog jezika Vladimira Anića.

2 Sva značenja pojma baština u ovom i drugim rječnicima navodit će se integralno. Smatram da se jednako mnogo može naučiti iz onoga što nedostaje, kao i iz onoga što je prisutno.
} 
nego i prirodna, nematerijalna ili svjetska baština. Komparativno bit će korisno pogledati englesku, francusku i njemačku definiciju istog pojma.

The Merriam-Webster Dictionary opisuje baštinu kao:

(1) property that descends to an heir

(2) a: something transmitted by or acquired from a predecessor: legacy, inheritance

b: tradition <the party's heritage of secularism>

(3) something possessed as a result of one's natural situation or birth: birthright The Oxford Dictionary pojam baštine opisuje na sljedeći način:

(1) Property that is or may be inherited; an inheritance

a. Valued objects and qualities such as historic buildings and cultural traditions that have been passed down from previous generations

b. Denoting or relating to things of special architectural, historical, or natural value that are preserved for the nation

c. Denoting a traditional brand or product regarded as emblematic of fine craftsmanship

d. Denoting a breed of livestock or poultry that was once traditional to an area but is no longer farmed in large numbers

e. (of a plant variety) not hybridized with another; old-fashioned

(2) (archaic) A special or individual possession; an allotted portion

(3) (archaic) Christians, or the ancient Israelites, seen as God's chosen people.

Iz navedenog možemo vidjeti da je imovina (dobro) te posjed i dalje u fokusu definicije, a vlasništvo nad nečim sastavni je dio pojma baština. Važno je naglasiti da The Merriam-Webster Dictionary uvodi i pojam tradicija kao onaj koji se usko veže uz baštinu, dok The Oxford Dictionary vrlo detaljno opisuje baštinu kao vrijedne predmete i običaje koji se prenose s generacije na generaciju i čuvaju za narod.

U francuskom jeziku postoje dva slična pojma koji odgovaraju pojmu baštine - le héritage i le patrimoine. Rječnik Larousse pojam le héritage definira kao:

(1) Imovina prenesena ili stečena sukcesijom : Ostavio je svojoj djeci važnu ostavštinu

(2) Ono što imamo u odnosu na pretke, prethodne generacije, u smislu značaja, ideologije itd. : Bogata kulturna baština

(3) Ono što su ostavili prethodnici i što je teško preuzeti/prihvatiti : Teško naslijeđe prethodne vlade. ${ }^{3}$

\footnotetext{
${ }^{3}$ Originalni navod: (1) Bien(s) acquis ou transmis par voie de succession : II a laissé à ses enfants un héritage important. (2) Ce qu'on tient de prédécesseurs, de générations antérieures, sur le plan du caractère, de l'idéologie, etc. : Un riche héritage culturel. (3) Ce qui est laissé par les prédécesseurs et qui est pénible à assumer : Le lourd héritage du gouvernement précédent.
} 
S druge pak strane pojam le patrimoine opisan je kao:

(1) Imovina naslijeđena od svojih predaka

(2) Ono što se smatra vlastitim dobrima, bogatstvom: Njegova je baština njegova inteligencija

(3) Ono što se smatra zajedničkom baštinom neke skupine: Kulturna baština neke države

(4) Sva imovina, prava i obveze ekonomske vrijednosti koje osoba može imati ili posjedovati

(5) Svi prisvojeni i prijenosni elementi koji su u određenom trenutku u vlasništvu bilo koje osobe, obitelji, tvrtke ili javnog tijela. ${ }^{4}$

Riječ je o svojevrsnim sinonimima što je vidljivo iz primjera: "Un riche héritage culturel" - bogata kulturna baština, i "Le patrimoine culturel d'un pays" - kulturna baština neke zemlje. Pojam patrimoine culturel pojavljuje se u 17. stoljeću i više je prisutan u latinskom svijetu (poput izraza u talijanskom jeziku - beni culturali) te danas uobičajeniji kao onaj koji se odnosi na kulturnu baštinu, nego na naslijeđe. To se naslanja na pojmove sličnog značenja u latinskom jeziku - heredium i patrimonium.

$\mathrm{S}$ druge pak strane $\mathrm{u}$ anglosaksonskom svijetu dulje je prisutan izraz property $\mathrm{u}$ smislu naslijeđa, što se mijenja nakon 1950-ih godina kad nastaje značenjska distinkcija između pojmova heritage i legacy (Desvallées i Mairesse 2010:64). Definicije ovih pojmova u velikoj se mjeri podudaraju s definicijom u hrvatskom jeziku.

U njemačkom jeziku također možemo prepoznati dva slična pojma - das Erbe i die Erbschaft. Rječnik Duden opisuje pojam das Erbe kao:

(1) Imovina koju netko ostavlja nakon smrti i prelazi u posjed pravno ovlaštene osobe ili institucije

(2) Nešto što je preneseno u sadašnjost; nematerijalna [duhovna, kulturna] ostavština. $^{5}$

Die Erbschaft opisan je kroz sinonime: Erbe i Hinterlassenschaft.

Prvo značenje odnosi se na ono što je naslijeđeno, što se prenosi s predaka na

\footnotetext{
${ }^{4}$ Originalni navod: (1) Bien qu'on tient par héritage de ses ascendants. (2) Ce qui est considéré comme un bien propre, une richesse : Son patrimoine, c'est son intelligence. (3) Ce qui est considéré comme l'héritage commun d'un groupe : Le patrimoine culturel d'un pays. (4) Ensemble des biens, droits et obligations ayant une valeur économique dont une personne peut être titulaire ou tenue. (5) Ensemble des éléments aliénables et transmissibles qui sont la propriété, à un moment donné, d'une personne, d'une famille, d'une entreprise ou d'une collectivité publique.

${ }^{5}$ Originalni navod: (1) Vermögen, das jemand bei seinem Tod hinterlässt und das in den Besitz einer gesetzlich dazu berechtigten Person oder Institution übergeht. (2) Etwas auf die Gegenwart Überkommenes; nicht materielles [geistiges, kulturelles] Vermächtnis.
} 
nove generacije. Drugo, mnogo zanimljivije ističe nematerijalnu vrijednost naslijeđenog - nicht materielles Vermächtnis - u smislu duhovnosti i kulture.

U svom radu pod naslovom Undesirable Heritage: Fascist Material Culture and Historical Consciousness in Nuremberg autorica Sharon Macdonald pogrešno će protumačiti značenje pojma baština u njemačkom jeziku, a sukladno tomu iznijet će pogrešnu sliku o značenju toga pojma u Njemačkoj. Na samom početku rada ona navodi sljedeće (Macdonald 2006:9-10):

"My Collins German-English Dictionary (1980) gives two related German words for 'heritage': das Erbe and die Erbschaft. Turning to the German, I find das Erbe first explained as 'heir' and then given a separate entry as follows:

Erbe nt -s, no pl inheritance; (fig) heritage; (esp unerwünschtes) legacy. das $\sim$ des Faschismus the legacy of fascism.

'Unerwünschtes' means 'undesirable' or 'un-wished-for'. 'Heritage' is, thus, described as an undesired legacy. The only gloss given, 'the legacy of fascism', effectively explains this primary interpretation. The entry for die Erbschaft is almost identical:

Erbschaft $f$ inheritance. eine $\sim$ machen or antreten to come into an inheritance; die $\sim$ des Faschismus the legacy of fascism.

As these dictionary entries indicate, the idea of 'heritage' in Germany has come to be bound up with a particular past: that of fascism."

Ne treba smetnuti s uma činjenicu da je Macdonald prilikom definiranja i razumijevanja pa i interpretacije ovog pojma, koristila rječnikom The Collins English Dictionary britanskog izdavača HarperCollins. ${ }^{6}$ Dakle, percepcija značenja ovdje navedenog pojma odnosi se na percepciju Britanaca na navedeni pojam u njemačkom jeziku više nego Nijemaca samih. Kao što je ranije rečeno, ekvivalentni rječnik njemačkog jezika, Duden, ne navodi ništa slično. Ipak, poprilično je znakovita pretpostavka Macdonald da bi navođenje nekog primjera upotrebe pojma (tj. riječi) mogla biti znakovita za neki narod u cjelini. S druge pak strane, sasvim je legitimno postaviti pitanje o opravdanosti i svrsi navedene interpretacije i primjera u britanskom rječniku i njegova izravnog povezivanja s pojmom fašistička baština. Dakle, "nepoželjnost" naslijeđa ovdje je percipirana od strane drugoga (Britanci) prema Nijemcima, nikako od strane Nijemaca samih, što je ključna tvrdnja Macdonald. No, unatoč ovoj pogrešnoj

\footnotetext{
${ }^{6}$ Mrežna verzija The Collins rječnika engleskog jezika kod pojma das Erbe više ne navodi primjer "fašističkog naslijeđa/baštine", no on je i dalje prisutan kod pojma die Erbschaft kao: "die Erbschaft des Faschismus - the legacy of fascism". Izvor: www.collinsdictionary.com/dictionary/germanenglish/erbschaft (pristup 14. 7. 2019.).
} 
interpretaciji, njezina teza o "neželjenoj" baštini, dalje razrađena u radu i kasnijim radovima na tu temu, neće biti pogrešna. Nijemci su u tom pogledu postigli mnogo više nego mnogi drugi narodi. Ipak, njihova percepcija njih samih ne ide nužno i isključivo kroz prizmu svoje "neželjene" prošlosti, što je između ostalog vidljivo i iz Dudenove definicije pojma baština kao nečega što se vezuje uz "duhovnost i kulturu". Dakle, rječnik kao jezična baština nekog naroda podjednako je pod utjecajem raznih politika, ali i različitih (ponekad i pogrešnih) tumačenja, kao i bilo koji drugi aspekt baštine. $O$ tome će svakako biti govora i u nastavku ovog rada.

Jasno vidljiv naglasak prisutan kod svih navedenih rječničkih definicija jest na naslijeđu u smislu vlasništva i imovine te u distinkciji s baštinom koja također predstavlja svojevrsno naslijeđe, ali u smislu kulture, tradicije, duhovnih vrijednosti i sl. lako postoji distinkcija u značenjskom smislu između onoga što u hrvatskom jeziku možemo razlikovati kad kažemo naslijeđe (imovina) i baština (kultura i tradicija), sasvim je neosporno i indikativno kako je vlasništvo vrlo važna komponenta u određivanju pojma baština - jer ona nekome pripada, bio to pojedinac, zajednica, društvo ili čovječanstvo u cjelini. Kulturna i prirodna baština nešto je što nam svima, u određenom smislu, pripada, pa nas slijedom toga i određuje i snažno utječe na naša identitetska obilježja.

Problem vlasništva, tj. posjedovanja baštine posebno je obrađen u radu A museum object, sacred, yet fragile - a lesson of the Croatian museum transition (Stublić 2018). Onaj tko posjeduje neki aspekt baštine, može joj dodavati i oduzimati značenja ovisno o kontekstu i društvenim promjenama. Nekad "sveti" muzejski/baštinski predmet jednim činom/odlukom može preko noći postati "desakraliziran", tj. demuzealiziran - odznačen kao baština - poništen zbog nepoželjnosti ili bezvrijednosti. Ovakav reverzibilan karakter baštine smatra se muzealizacijskim paradoksom (ibid.:204). U Hrvatskoj se kao primjer mogu uzeti zbirke brojnih muzeja revolucije i narodnooslobodilačke borbe, koji su nakon raspada Jugoslavije 1990-ih rasformirani, a zbirke uklopljene u novonastale muzeje (poput Hrvatskoga povijesnog muzeja u Zagrebu). Neke su predmeti pak izlučeni iz zbirki (često odbačeni na smetlišta), ukradeni, rasprodani ili u potpunosti fizički uništeni zbog svoga novonastalog karaktera neželjene baštine. Dakle, onaj tko posjeduje ima slobodnu volju da o vlastitom vlasništvu donosi odluke, ma kakve god one bile.

Jezična komparativna analiza pojma baština pomaže nam u razumijevanju različitost značenja koja se pojavljuju (u ovom slučaju) kod "većih" jezika na europskom kontinentu. Uz to ona upućuje i na osjetljivo pitanje prijevoda s jednog jezika na drugi, koji je uvijek i nužno svojevrsna interpretacija značenja teksta te potraga za pravim smislom. Ta potraga usporediva je s činom interpretacije koji se svakodnevno događa prilikom komuniciranja nekog aspekta baštine od strane stručnog djelatnika prema posjetiteljima u različitim baštinskim institucijama i različitim medijima (izložba, vodstvo, katalog, predavanje i sl.). 
Osim strogo jezičnog definiranja pojma baština nužno je posegnuti za nekim detaljnijim razmatranjima toga pojma unutar pojedinih znanstvenih disciplina ili stručnih organizacija. Pritom valja i dalje imati na umu tko je interpretator toga pojma (tko ga definira) i u kojem se kontekstu spominje. Najopsežniji dijakronijski prikaz definicija pojma baština objavljen je prvi put 1990. godine u sklopu ICCROM-ove radne grupe Heritage and Society (ICCROM 1990). Navedeni dokument sadrži preko 60 definicija pojma baština i čini glavnu referentnu točku za daljnja proučavanja toga pojma.

Za potrebe ovog rada osvrnut ćemo se na definiciju iz 1989. godine koja je predstavljena na Općoj konferenciji UN-ove svjetske organizacije za obrazovanje, znanost i kulturu (UNESCO 1989):

"Kulturna baština može se definirati kao cjelokupni korpus materijalnih znakova - bilo umjetničkih ili simboličkih - koji se prenose iz prošlosti u svakoj kulturi i, prema tome, cjelokupnom čovječanstvu. Kao sastavni dio afirmacije i obogaćivanja kulturnog identiteta, kao naslijeđa koje pripada cjelokupnom čovječanstvu, kulturna baština daje svakom pojedinom mjestu svoje prepoznatljive osobine i čini skladište ljudskog iskustva. Očuvanje i prezentacija kulturne baštine stoga su kamen temeljac bilo koje kulturne politike."

No ono što je u ovoj definiciji nedvojbeno jasno jest da se baština kao takva vezuje nužno uz identitete i iskustvo. U tom smislu može se zaključiti da baština ne postoji bez subjekta koji je posjeduje i koji na njoj temelji svoje identitete. Ako je to doista tako, tko je stvarni kreator baštine? U danoj UNESCO-ovoj definiciji neizbježan je i ranije spomenuti pozitivan ton baštine kao nečega što je sastavni dio cjelokupnog čovječanstva i u tom pogledu nešto vrijedno čuvanja i prezentiranja.

Ovako percipirana i definirana (kulturna) baština predmet je proučavanja mnogih disciplina koje, fokusirajući se na specifične materijalne baštinske segmente, također problematiziraju njezinu narav i bit. Tako kod autora poput Françoise Choay, francuske povjesničarke i teoretičarke koja se bavi pitanjima arhitekture i urbanizma, pronalazimo ekstenzivno istraživanje pojma i pojave povijesnog spomenika (spomenika kulture) te njegovo kritičko propitivanje u smislu značenja i nastanka te promjene kroz povijesna razdoblja. Choay tako u svom radu The Invention of the Historic Monument ${ }^{7}$ (Choay 2001:12) navodi kako je nemoguće promišljati o pojmu povijesnog spomenika (ili njegovoj zaštiti) odvojeno od konteksta u kojem je nastao:

\footnotetext{
${ }^{7}$ Knjiga je objavljena prvi put u Francuskoj 1992. pod naslovom L'Allégorie du patrimoine. Prijevod na engleski jezik u izdanju Cambridge University Pressa napravila je Lauren M. O'Connell (2001.). $S$ jezičnog stanovišta zanimljivo je promotriti razliku u naslovu.
} 
"To adopt the conservational practices of historic monuments without benefit of an historic frame of reference, without attributing a particular value to time and to the passage of time, without having inserted art into history, is as meaningless as practicing the tea ceremony without being familiar with the Japanese conception of nature, Shintoism, and the structure of Japanese social relations."

Svoje promišljanje o baštini ističe navodom kako navedeni koncept "vodi u semantičku homogenizaciju vrijednosti, koji različitim procesima doprinosi samoreprodukciji" (ibid.:66). Upravo iz toga razloga ne treba pojam baštine uzeti zdravo za gotovo, tj. smatrati da je (semantička) homogenizacija vrijednosti koja ga obilježava pozitivan proces. On svakako može u određenim trenucima poslužiti kao nositelj argumenata u korist zaštite, no na mnogim razinama homogenizacija vrijednosti baštine nije nužno dugoročno pozitivan proces jer se može negativno odraziti na niz manjih baštinskih sklopova koji se ne uklapaju u jedinstvenu viziju baštine.

S druge pak strane zanimljivo je primijetiti da Međunarodno vijeće muzeja (engl. International Council of Museums - ICOM) u svojoj publikaciji Key Concepts of Museology (Desvallées i Mairesse 2010) ne donosi nikakvu preciznu (ili konačnu) definiciju pojma baština, nego njegovu ekstenzivnu genealogiju oslanjajući se na važne teoretičare u polju i UNESCO-ovu ranije spomenutu definiciju. Smatram kako možemo zaključiti da je, kada govorimo o pojmu baštine, to znak svojevrsne kompleksnosti pojma, višedimenzionalnosti i ovisnosti u odnosu na poziciju i perspektivu koja se zauzima prilikom njegova definiranja. Ipak, ova publikacija sadrži neka vrlo zanimljiva razmatranja pojma baština i sam dokument služi kao dobra osnova za daljnju analizu. Citirajući navod Laurajane Smith iz 2006. godine autori ICOM-ove publikacije navode:

"Heritage is a cultural process or performance that is concerned with the types of production and the negotiation of cultural identity, individual and collective memory, and social and cultural values' (Smith, 2007). If we accept that heritage is the result of the founding of a certain number of values, this implies that these values are the basis of heritage. These values should be examined, but also - sometimes - contested." (Desvallées i Mairesse 2010:41)

Smith vrlo promišljeno i precizno identificira, definira i demistificira pojam baština kao nešto što nije samo po sebi prisutno (i tek čeka da bude otkriveno), nego da je riječ o procesu (pa i izvođenju u smislu čina), dakle nešto što nastaje djelovanjem pojedinaca ili skupina, a uključuje različite oblike proizvodnje koji dogovorno povezuju identitete, sjećanja i vrijednosti neke zajednice. Dakle, ono što se nalazi u srži baštine jesu identiteti 
i vrijednosti, a baština sama po sebi nema vrijednost (pa čak i ne postoji) ako nije u korelaciji s tim pojmovima. Ono što čini zanimljivom ovu raspravu jest komentar autora ICOM-ove publikacije koji smatraju da je baština temeljena na određenim vrijednostima, ali da te vrijednosti moraju biti istražene i preispitane, pa ponekad i osporene. Ovakav stav naslanja se na ideju Smith i drugih teoretičara (Macdonald 2006, 2009; Harrison 2013) kako baština nije samo isključivo i nužno pozitivna pojava nego da ponekad uključuje i dvojbene ili problematične elemente. Dakle, možemo govoriti samo o baštini, ali i afirmativnoj, "herojskoj" baštini u opoziciji prema "spornoj" baštini.

No, da bismo u potpunosti razumjeli poziciju koju zauzima Smith i drugi moramo uzeti u obzir da je, u odnosu naspram definicije kulturne baštine, UNESCO 2003. godine usvojio Konvenciju o zaštiti nematerijalne kulturne baštine. U njoj se jasno definira nematerijalna kulturna baština kao:

"(...) the practices, representations, expressions, knowledge, skills - as well as the instruments, objects, artefacts and cultural spaces associated therewith - that communities, groups and, in some cases, individuals recognize as part of their cultural heritage. This intangible cultural heritage, transmitted from generation to generation, is constantly recreated by communities and groups in response to their environment, their interaction with nature and their history, and provides them with a sense of identity and continuity, thus promoting respect for cultural diversity and human creativity. For the purposes of this Convention, consideration will be given solely to such intangible cultural heritage as is compatible with existing international human rights instruments, as well as with the requirements of mutual respect among communities, groups and individuals, and of sustainable development."

Navedena definicija uvodi i na prvo mjesto stavlja one pojedince, grupe ili zajednice ljudi koji prakticiraju nematerijalnu kulturnu baštinu, stavljajući time u fokus sam čin zaštite koji se događa i provodi samo ako se prakticira od strane onih koji posjeduju navedenu nematerijalnu baštinu. Drugim riječima, i na tragu onoga što Smith naglašava kada govori da je baština proces i performans, nema baštine bez onoga koji tu baštinu izvodi. Samo priznavanje i definiranje nematerijalne baštine svodi cijelu raspravu o naravi i biti baštine upravo na pitanje egzistencije baštine (u materijalnom i nematerijalnom obliku) izvan onih kojim ta baština pripada ili je prakticiraju. Tim više, ovako postavljena teza navodi na zaključak da ne postoji segment materijalne baštine koji u sebi ne nosi određeni nematerijalni aspekt. Jer naime, nematerijalna baština ne postoji ako ne poprima neki svoj fizički ili izvedbeni oblik u vremenu i prostoru, kao što ne postoji ni materijalna baština bez svojega nematerijalnog aspekta koji upravo taj 
predmet/spomenik/građevinu i sl. čini onime što ona jest.

Osim same definicije nematerijalne kulturne baštine, u preambuli Konvencije jasno se navodi da "zajednice, s posebnim naglaskom na zajednice starosjedilaca, grupe ljudi ili ponekad pojedinci imaju važnu ulogu u stvaranju, zaštiti, održavanju i rekreiranju nematerijalne kulturne baštine, čime doprinose obogaćivanju kulturne raznolikosti i ljudske kreativnosti". Dakle, baština postoji tamo gdje postoje ljudi, oni baštinu stvaraju ili je poništavaju, dodaju ili oduzimaju značenja i vrijednosti te identitete koje za nju vežu, ali tu istu baštinu mijenjaju protokom vremena, promjenom vlastitih potreba i okolnosti u kojima se nalaze.

Upravo ta svijest o različitim društvenim okolnostima koje nas okružuju i sve veća kritika tradicionalnih perspektiva koje se perpetuiraju i osnažene su od strane konzervativnih struja unutar društveno-humanističkih znanstvenih disciplina potaknule su niz pokreta ${ }^{8}$ na polju proučavanja baštine. Jedan od njih svakako je i osnivanje Udruženja kritičkih studija baštine (engl. Association of Critical Heritage Studies ACHS) ${ }^{9}$ 2010. godine. Skupina znanstvenika okupljena oko zajedničke ideje o kritičkoj perspektivi u odnosu na baštinu, tzv. critical heritage studies, objavila je 2012. godine manifest djelovanja. U uvodu manifesta stoji sljedeće (ACHS 2012):

"Heritage is, as much as anything, a political act and we need to ask serious questions about the power relations that 'heritage' has all too often been invoked to sustain. Nationalism, imperialism, colonialism, cultural elitism, Western triumphalism, social exclusion based on class and ethnicity, and the fetishising of expert knowledge have all exerted strong influences on how heritage is used, defined and managed. We argue that a truly critical heritage studies will ask many uncomfortable questions of traditional ways of thinking about and doing heritage, and that the interests of the marginalised and excluded will be brought to the forefront when posing these questions."

Izrazito je važno naglasiti ACHS-ov stav kojim izravno baštinu smatraju političkim činom te direktnom vezom u odnosima moći. I doista, baština je sve samo ne sama sebi svrhom. Isto će postati još vidljivije kroz temu teške baštine koja uvijek i gotovo bez iznimke podrazumijeva neki oblik političkog i društvenog sukoba.

Ovo Udruženje već godinama okuplja stručnjake i znanstvenike svih profila koji, svjesni nužnosti kritičkog pogleda na postojeći konvencionalni koncept baštine, razvijaju i organiziraju različite aktivnosti s ciljem poticanja diskusije i podizanja svijesti o smislu i

\footnotetext{
${ }^{8}$ U muzeologiji možemo pratiti uspon tzv. Nove muzeologije. Više o tome na: MINOM - International Movement for a New Museology, http://icom.museum/the-committees/affiliated-organisations/ affiliated-organisation/international-movement-for-a-new-museology/ (pristup 14. 7. 2019.)

9 Jedna od osnivačica ovog udruženja jest teoretičarka Laurajane Smith.
} 
svrsi baštine u današnjem svijetu. Posebice je naglašena problematika tzv. autoriziranoga baštinskog diskursa (engl. authorised heritage discourse) koji, prema riječima Smith (2006:11), promiče "kulturne vrijednosti zapadnih elita kao univerzalne". Razvojem svijesti o pozicijama i izvorištima koji se nalaze u pozadini baštinskih tema razvilo se i plodno tlo za propitivanje ustaljenih obrazaca i redefiniciju postojećih pojmova te uspostave nekih novih koji će točnije opisivati sve složenije područje istraživanja baštine.

\section{O POJMU TEŠKE BAŠTINE}

Prilikom navođenja primjera teške baštine u svijetu gotovo je neizbježna tema zločina počinjenih od strane nacista za vrijeme Drugoga svjetskog rata. Razmjeri ovog zločina kao i broj stradalih dio su kolektivnog sjećanja cijele Europe (pa i dijela ostatka svijeta) i u mnogim aspektima trajno su obilježili ovaj prostor i ljude. Riječ je o teškoj baštini u punom smislu toga pojma. No, pravo je pitanje: čija je to točno teška baština? Ona je nesumnjivo teška za sve one koji su stradali i one koji nose sjećanje na preživljene strahote i njihove potomke. Također, ona je nesumnjivo teška baština i za sve one koji su direktno ili indirektno odgovorni za sam zločin pa i njihove potomke koji sa samim zločinom nemaju direktne veze osim činjenice da su potomci ili pripadnici naroda koji su sudjelovali u provođenju ili podupiranju nacističkog režima. Ovdje se možemo vratiti na početak rada i primjer rječničke definicije teške baštine Sharon Macdonald koja je ilustrirana kroz naslijeđe njemačkog fašizma (nacizma), ali kao što smo vidjeli, kao takva se ne javlja u njemačkom rječniku Duden. Dakle, afirmacija ili negacija istoga proteže se kroz različite politike i različite aktere ove priče. Ipak, potreba za suočavanjem s ovim dijelom njemačke povijesti snažno je prisutna u njemačkom narodu i kao takva je neizbježna prilikom kreiranja i provođenja raznih politika na nacionalnoj razini. Razlog tomu ogleda se ne samo u potrebi njemačkog naroda nego i u pritisku svih ostalih sudionika ili stradalih u navedenim događajima, a koji direktnim ili indirektnim metodama podupiru održavanje sjećanja na zločine počinjene u Drugom svjetskom ratu.

Možda stoga ne treba čuditi što je njemački povjesničar umjetnosti Norbert Huse već 1997. godine objavio knjigu znakovitog naslova Unbequeme Baudenkmale: Entsorgen? Schützen? Pflegen?. ${ }^{10}$ On propituje vrijednosti i značenja ne samo "lijepih spomenika arhitekture nego i onih ne tako lijepih", tj. onih za koje smatra da imaju značajnu povijesnu vrijednost. Očekivano, primjere koje navodi odnose se na brojna arhitektonska zdanja nastala za vrijeme nacizma u Njemačkoj no također i u vrijeme nakon Drugoga svjetskog rata, pogotovo u tadašnjem Istočnom Berlinu. Huse je predvodnik

${ }^{10}$ Slobodan prijevod: Neugodni spomenici arhitekture: Zbrinuti? Zaštititi? Održavati? 
struje koja se suprotstavlja svojevrsnom ikonoklastičkom pristupu u njemačkom društvu koje, vodeći se upravo autoriziranim baštinskim politikama i diskursima (kako in naziva Smith i ostali), naginje stavu da "neželjena" baština nema mjesto u današnjem društvu. Huse smatra da takvi spomenici svakako moraju biti sačuvani, pa i obnovljeni, no ne bježi od činjenice da je provođenje zaštite takvih spomenika u praksi vrlo zahtjevan i kompleksan proces koji u sebi nosi brojne probleme. U tom smislu posebno naglašava kako su navedeni arhitektonski povijesni spomenici iznimno važni jer svojim bivanjem i pojavnošću u prostoru i životu nekog grada/mjesta najintenzivnije svjedoče o vremenu u kojem su nastali. Uz to navodi da je sačuvani Berlinski zid zapravo svojevrsni javni spomenik i dokument jednog vremena, kakav ne može biti nijedan novopostavljeni javni spomenik. Pojam teške baštine kod Husea javlja se i u podnaslovu navedene knjige kao Schwierige Erbschaften - dakle teško naslijeđe/baština - a za koje smatra da ne može biti sačuvano ni ispuniti određenu društvenu ulogu ako ne postoji snažna društvenopolitička podrška praćena visokom razinom svijesti o navedenoj problematici i njezinim društveno i povijesno važnim aspektima.

Svega godina dana prije Norberta Husea, Ashworth i Tunbridge objavljuju knjigu pod naslovom Dissonant heritage: the management of the past as a resource in conflict (Ashworth i Tunbridge 1996:21) u kojoj uvode pojam tzv. disonantne baštine (engl. dissonant heritage) te ga opisuju ovim riječima:

"All heritage is someone's heritage and therefore logically not someone else's: the original meaning of an inheritance [from which 'heritage' derives] implies the existence of disinheritance and by extension any creation of heritage from the past disinherits someone completely or partially, actively or potentially. This disinheritance may be unintentional, temporary, of trivial importance, limited in its effects and concealed; or it may be long-term, widespread, intentional, important and obvious."

Ashworth i Tunbridge svoju poziciju temelje na definiciji baštine kao nečega naslijeđenog od prethodnih generacija ili iz prošlosti, a posjedovanje toga ultimativna je pozicija koja omogućava nekoj društvenoj grupi da s tim radi kako smatra da je za nju najbolje, bilo da je riječ o bacanju u zaborav dijela prošlosti ili slavljenje kroz rituale. Posjedovanje materijalnog nužno je kako bi se posjedovalo i sve ono nematerijalno što je vezano uz određeni baštinski element. Jer u nematerijalnom prebiva sve ono što se izravno veže uz identitete i vrijednosti. Također, posjedovanje nekog dijela baštine u ovom kontekstu predstavlja moć.

O teškoj baštini govori Sharon Macdonald 2007. na Godišnjoj konferenciji ICOMova Komiteta za arheološke i povijesne muzeje i zbirke (ICMAH). Ona točno identificira tešku baštinu kao jedan aspekt baštine koji je nužno povezan s identitetima neke grupe 
Ijudi, a koji se u vlastitoj identifikaciji i prezentaciji često negira. ${ }^{11}$ Negiranje proizlazi iz nemogućnosti sagledavanja baštine ili identiteta unutar negativnog spektra, ali i odbijanja postojanja takvih negativnih aspekata s ciljem izgradnje isključivo pozitivne slike o sebi. Pogrešno se tumači izgradnja vlastitih identiteta i vrijednosti kroz pozitivne aspekte života, kao ono što je jedino ispravno i poželjno te osnažuje zajednicu. Upravo se $u$ načinu njezina nošenja s negativnim aspektima prošlosti ili identiteta ogleda stvarna snaga neke zajednice ili društva. Drugim riječima rečeno, prava snaga očituje se u mogućnosti suočavanja s cjelokupnom našom prošlošću, a ne samo isticanje onih neupitno pozitivnih aspekata. Dok prvi pristup zahtijeva visoku razinu samosvjesnosti i želju za gradnjom na čvrstim i zdravim temeljima, drugi pristup samo je podilaženje kolektivnom egu i neiskreno i samozavaravajuće djelovanje. Prvi čini progresivnu snagu zajednice, a drugi održava status quo.

Zanimljiva je činjenica da Macdonald već 2015. godine u članku Is 'Difficult Heritage' Still 'Difficult'? - Why Public Acknowledgment of Past Perpetration May No Longer Be So Unsettling to Collective Identities, analizirajući pozitivne primjere iz Njemačke koji svjedoče o brizi za tešku baštinu te mogućem "iscjeljujućem" djelovanjem koje ima na društvo, dovodi u pitanje samu kompleksnost i težinu zaštite, interpretacije ili prezentacije teške baštine. S jedne strane gledano, ovako postavljeno pitanje sasvim je legitimno, no prilikom toga ipak moram uzeti u obzir da se razmjeri i načini kojima se Njemačka bavi vlastitim teškim naslijeđem ipak ponešto razlikuju i bivaju iznimkom ako uzmemo u obzir kako se sličnom problematikom nose druge države i narodi.

Ovdje ćemo još spomenuti i zbornik radova Places of Pain and Shame: Dealing with 'Difficult Heritage' nastao pod uredništvom Logana i Reevesa 2009. godine koji čini zanimljivu kompilaciju članaka i primjera teške baštine podijeljenih u četiri kategorije: mjesta masakra i genocida, mjesta ratnog zatočeništva, civilni i politički zatvori i mjesta benevolentne internacije. U svom predgovoru Logan i Reeves posebno naglašavaju važnost identificiranja i prezentacije lokaliteta teške baštine kao mjesta sjećanja, a naslanjajući se na poznatu tezu Pierrea Nora (1989) o baštinskim lokalitetima kao posebnim mjestima sjećanja i pamćenja - lieu de mémoire - nužnima za razumijevanje društva te izgradnju budućnosti.

S obzirom na karakter teške baštine razumljiva je potreba za pojmovnom distinkcijom u odnosu na ustaljeni i tradicionalno afirmativni pojma baština koji, često kao dio tradicionalnog pogleda i razumijevanja baštine, zamagljuje (a ponekad i negira) sve aspekte baštine, a posebice "spornu" baštinu. U tom smislu baština je lice, a teška baština naličje istog fenomena.

\footnotetext{
${ }^{11}$ Sharon Macdonald izdala je godine 2009. knjigu pod naslovom Difficult Heritage: Negotiating the Nazi Past in Nuremberg and Beyond u izdanju Routledgea.
} 


\section{TRI PRIMJERA (TEŠKE) BAŠTINE}

U nastavku rada bit će prezentirana tri primjera teške baštine u Njemačkoj, Hrvatskoj i Južnoj Koreji. Analiza ovih primjera pružit će detaljniji uvid u kontekst, okolnosti i problematiku teške baštine u praksi. Sva tri primjera, iako se nalaze u različitim kontekstima i odnose se na različite povijesne događaje, ipak povezuje jedinstveni zajednički nazivnik - svi su izronili iz događaja vezanih uz Drugi svjetski rat.

\section{Primjer prvi - Berlin, Njemačka}

Jedan od većih projekata i pokušaja da se obilježi stradanje Židova za vrijeme nacizma jest izgradnja Memorijala ubijenim Židovima Europe (engl. Memorial to the Murdered Jews of Europe, njem. Denkmal für die ermordeten Juden Europas) izgrađen 2005. godine prema projektu arhitekta Pietera Eisenmana. Memorijal se nalazi u samom centru Berlina, svega nekoliko stotina metara od Brandenburških vrata. Važnost memorijala očituje se, osim lokacije, i u njegovoj veličini jer zauzima prostor od jednoga cijelog stambenog bloka, dakle oko $19000 \mathrm{~m}^{2}$ na kojima se nalazi oko 2700 betonskih blokova. ${ }^{12} \mathrm{U}$ sklopu samog memorijala nalazi se i informacijski centar koji služi kao arhiv i centar za posjetitelje s izložbom posvećenom temi memorijala.

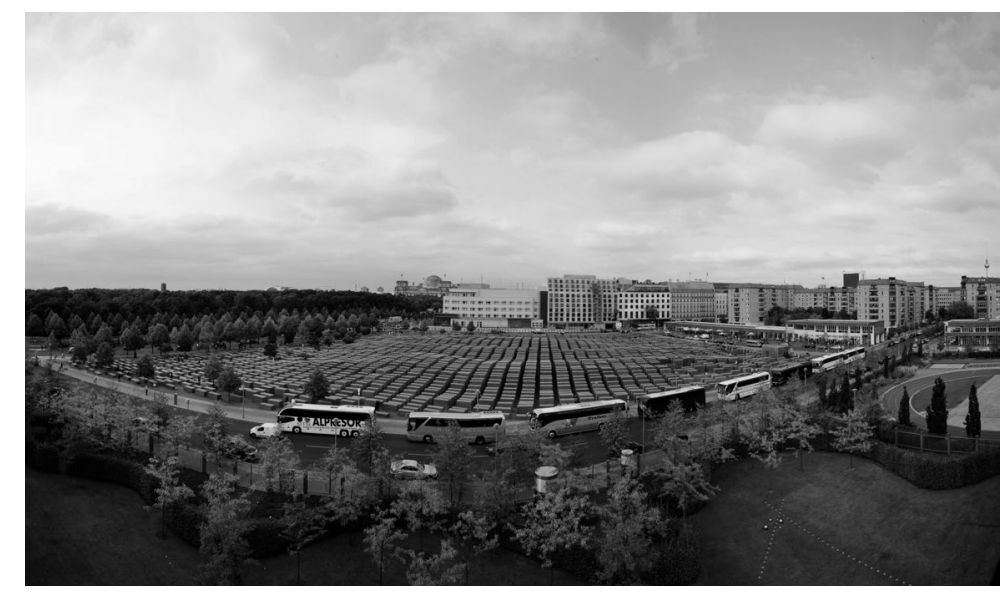

Slika 1: Panoramski prikaz Memorijala ubijenim Židovima Europe, Berlin (Foto: Marko Priske) (c) Foundation Memorial to the Murdered Jews of Europe

12 Detaljan opis spomenika nalazi se na stranici Fondacije i informacijskog centra: https://www. stiftung-denkmal.de/en/memorials/the-memorial-to-the-murdered-jews-of-europe/field-of-stelae.html (pristup 14. 7. 2019.). 
Inicijativa za oblikovanjem ovakvog memorijala javila se još 1980-ih godina, a do realizacije proteklo je nešto malo više od 15 godina. Ovo razdoblje obilježile su brojne rasprave o samoj svrsi ovakvog memorijala, kao i o formi i načinu na koji bi on bio oblikovan. Kritičara je bilo na svim stranama koji su memorijal smatrali nepotrebnim, nedostatnim ili pak naprosto neprimjerenim. Dakle, svoj su stav vrlo jasno artikulirali i Nijemci i Židovi, no u konačnici je projekt prepoznat od strane njemačkoga političkog establišmenta kao prioritetna tema. ${ }^{13}$ Projekt je nakon podulje rasprave usvojen u njemačkom parlamentu nakon čega je uspostavljena fondacija za njegovu izgradnju. lako su izgradnju memorijala pratile brojne kontroverze, najveća se odnosila na sam naziv memorijala posvećenog "ubijenim Židovima Europe". Naziv se smatrao nedorečenim i bez jasnog upućivanja na krivca ili sam povijesni trenutak, dakle na ubijene za vrijeme nacizma u Drugom svjetskom ratu. Drugi problem naziva očitovao se u isticanju samo stradalih pripadnika židovskog naroda, koji, iako je najbrojniji, nikako nije jedina stradala skupina ljudi za vrijeme nacizma. Za vrijeme nacističkog terora među stradalima su bili i pripadnici drugih društvenih skupina poput homoseksualaca, Roma, Poljaka i pripadnika ostalih slavenskih naroda, Jehovinih svjedoka i drugih.

No, ova priča fokusira se na događaje koji prate 2001. godinu kada je pokrenuta inicijativa pod nazivom Der homosexuellen NS-Opfer gedenken (engl. Remember the Homosexual Victims of National Socialism) pod vodstvom Njemačke organizacije lezbijki i gejeva (njem. Lesben- und Schwulenverband in Deutschland - LSVD) s ciljem podizanja memorijala u čast stradalim homoseksualcima za vrijeme nacističkog režima - Denkmal für die im Nationalsozialismus verfolgten Homosexuellen (engl. The Memorial to the Homosexuals persecuted under the National Socialist Regime). Ideja o podizanju memorijala postojala je još od vremena diskusija o memorijalu stradalim Židovima iz 1992. godine. Ona je odraz neslaganja s retorikom odvajanja žrtava nacizma, a jasan stav o takvom pristupu ovoj problematici očitovao se u lokaciji i formi memorijala. Naime, memorijal se nalazi preko puta Memorijala stradalim Židovima Europe na samom ulazu u park Tiergarten. Također, formom gotovo u potpunosti nalikuje jednom od betonskih blokova koji se nalazi u sklopu memorijala ubijenim Židovima s dodatkom jednoga manjeg otvora kroz koji je moguće vidjeti videorad koji prikazuje dva muškarca koji se ljube. ${ }^{14}$

\footnotetext{
${ }^{13}$ Važno je napomenuti kako je inicijativa došla 1988. godine od strane novinarke Lee Rosh koja je 1989. u suradnji s povjesničarom Eberhardom Jäckelom pokrenula civilnu inicijativu "Perspective Berlin" sa svrhom oblikovanja Memorijala ubijenim Židovima Europe. Godine 1992. projekt preuzima njemačka vlada pod vodstvom kancelara Helmuta Kohla. Više na web stranici Fondacije: https://www.stiftung-denkmal.de/startseite.html (pristup 29. 11. 2019.).

${ }^{14}$ lako nema bilješki o stradalim lezbijkama pod nacističkim režimom, na inzistiranje lezbijske zajednice, videofilm povremeno se izmjenjuje te prikazuje dvije lezbijke kako se ljude.
} 


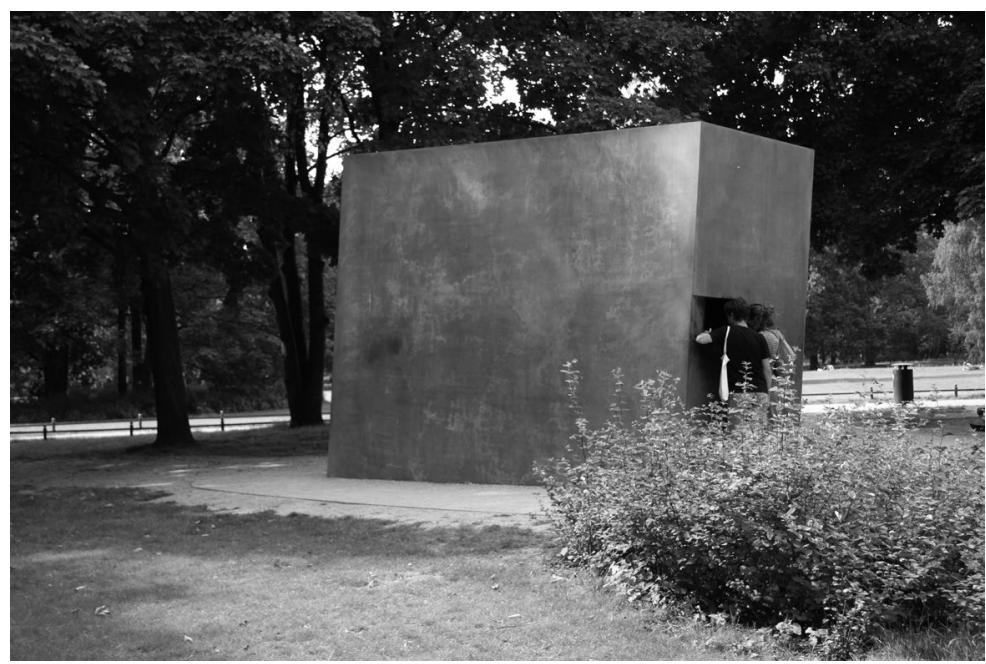

Slika 2: Memorijal stradalim homoseksualcima za vrijeme nacističkog režima, Berlin (Foto: Sabine Hauke) (c) Foundation Memorial to the Murdered Jews of Europe

Protivljenja postavljanju memorijala u ovoj formi i na ovome mjestu bila su brojna. Ipak, rezultat ovakvog djelovanja lezbijskih i gej organizacija u konačnici je rezultirao postavljanjem još dvaju sličnih memorijala: Denkmal für die im Nationalsozialismus ermordeten Sinti und Roma Europas (engl. The Memorial to the Sinti and Roma murdered under the National Socialist Regime) podignut 2012. godine i Der Gedenk-

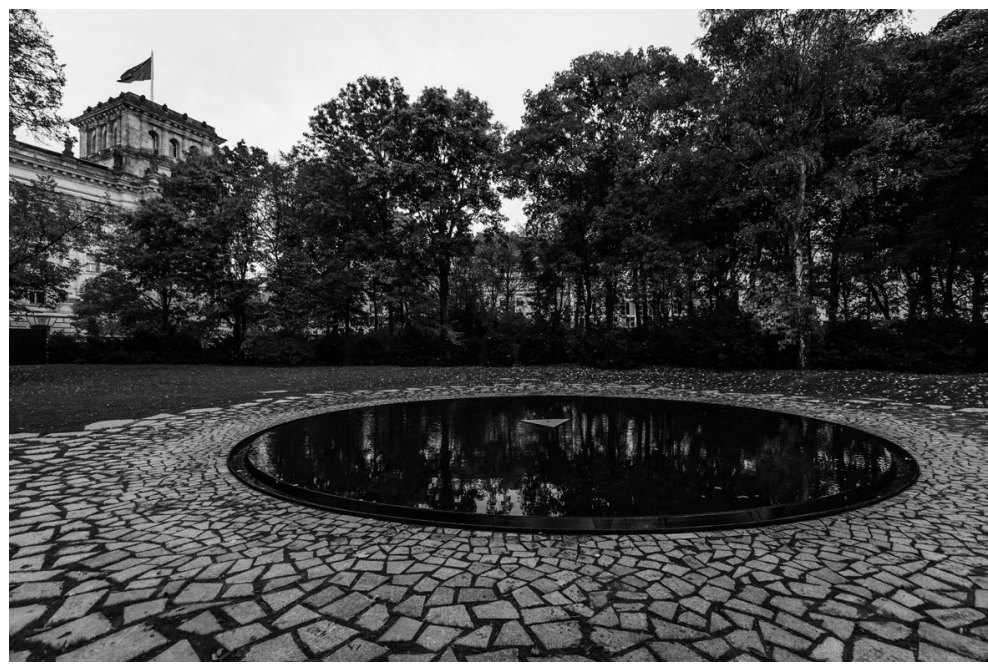

Slika 3: Memorijal ubijenim Sintima i Romima za vrijeme nacističkog režima, Berlin (Foto: Marko Priske) (c) Foundation Memorial to the Murdered Jews of Europe 


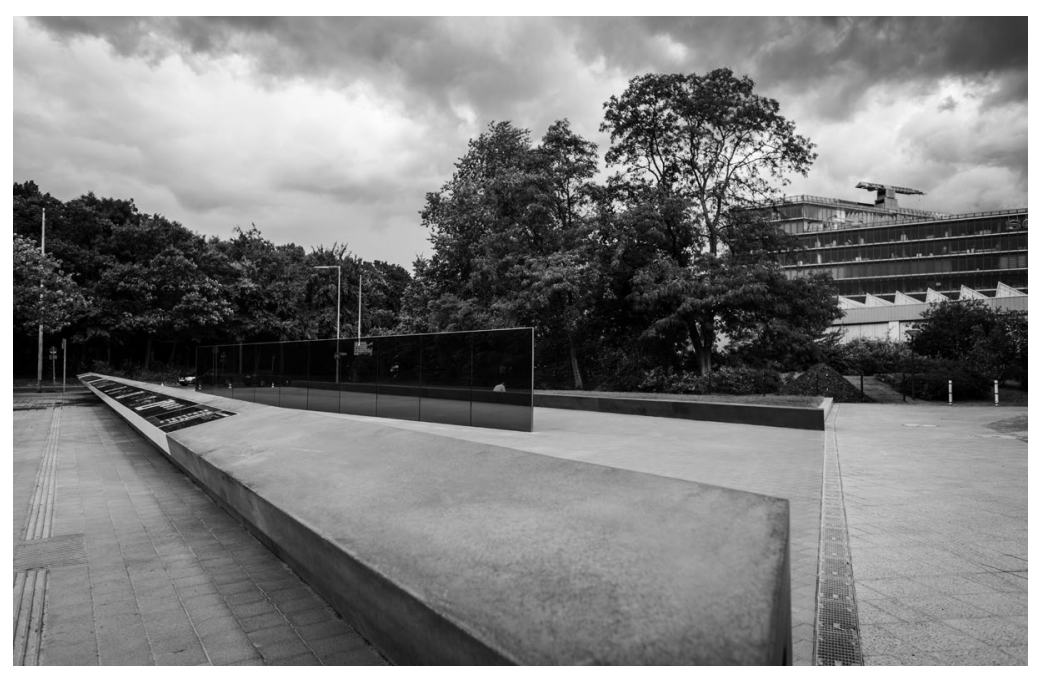

Slika 4: Memorijal i informacijska točka za žrtve "eutanazijskih" ubojstava, Berlin (Foto: Marko Priske) (c) Foundation Memorial to the Murdered Jews of Europe

und Informationsort für die Opfer der Nationalsozialistischen "Euthanasie"-Morde (engl. The Memorial and Information Point for the Victims of National Socialist "Euthanasia" Killings) iz 2013. godine. Drugi važan moment dogodio se upravo oko pitanja samog naziva tih spomenika gdje su jasno artikulirani odgovorni za zločine, dakle podupiratelji nacističkog režima. Treći pozitivan pomak vidljiv je u činjenici da su sami spomenici pridruženi Fondaciji Memorijala ubijenim Židovima Europe, dakle kao njegov punopravni i sastavni dio, a ne kao izdvojene priče. Inicijalno to nije bio slučaj.

\section{Primjer drugi - Zagreb, Hrvatska}

Drugi primjer posvećen je dvjema vrlo hrabrim sestrama - Zdenki i Rajki Baković. Sestre Baković bile su pripadnice antifašističkog pokreta otpora za vrijeme Nezavisne države Hrvatske (NDH) koja je tijekom Drugoga svjetskog rata bila saveznica nacističke Njemačke. Sestre Baković pomagale su pokretu otpora tako što su koristile vlastiti kiosk za prodaju novina u tadašnjoj Nikolićevoj ulici 7 (današnja Varšavska ulica) u Zagrebu kao mjesto sastanaka i centar za distribuciju informacija ostalim članovima pokreta otpora u Zagrebu. Njihov je rad uočila Ustaška nadzorna služba (UNS) te ih obje uhitila 20. prosinca 1941. godine. Sestre su bile izvrgnute višednevnim brutalnim mučenjima i ispitivanim kako bi izdale ostale članove pokreta otpora, no to ipak nisu učinile. Zdenka Baković ubila se prilikom jednog ispitivanja skokom kroz prozor 25. prosinca 1941., a 
Rajka Baković umrla je u bolnici 29. prosinca iste godine nakon što je podlegla ozljedama nakon mučenja. Zdenka je imala 24, a Rajka 21 godinu. Godine 1953. proglašene su narodnim herojima SFR Jugoslavije. ${ }^{15}$

One su bile prave heroine u mračnim vremenima Drugoga svjetskog rata na tlu današnje Hrvatske. Ali pravo pitanje glasi: kako je moguće da se priča o sestrama Baković smatra teškom baštinom?

Priča zapravo započinje 1990-ih godina u Zagrebu. Raspadom Jugoslavije i početkom Hrvatske borbe za neovisnost, započinje još jedan krvavi rat. Gotovo u trenutku, preko noći, cjelokupno naslijeđe povezano s Jugoslavijom postaje neželjena baština. U tom kontekstu spomenik sestrama Baković, podignut i slavljen za vrijeme Jugoslavije, postaje također neželjen. Spomenik se nalazi u samom centru Zagreba, preko puta mjesta gdje se nekada nalazio kiosk koji su koristile sestre Baković, u prolazu koji je dugo nosio također naziv Sestara Baković. Tijekom 1990-ih u okolnostima rata javlja se inicijativa za preimenovanjem prolaza u Miškecov prolaz. Miškec je prema urbanoj legendi bio lokalni siromah koji je živio u kotlovnici obližnjeg kina te zarađivao noseći na leđima reklamne panoe. ${ }^{16}$

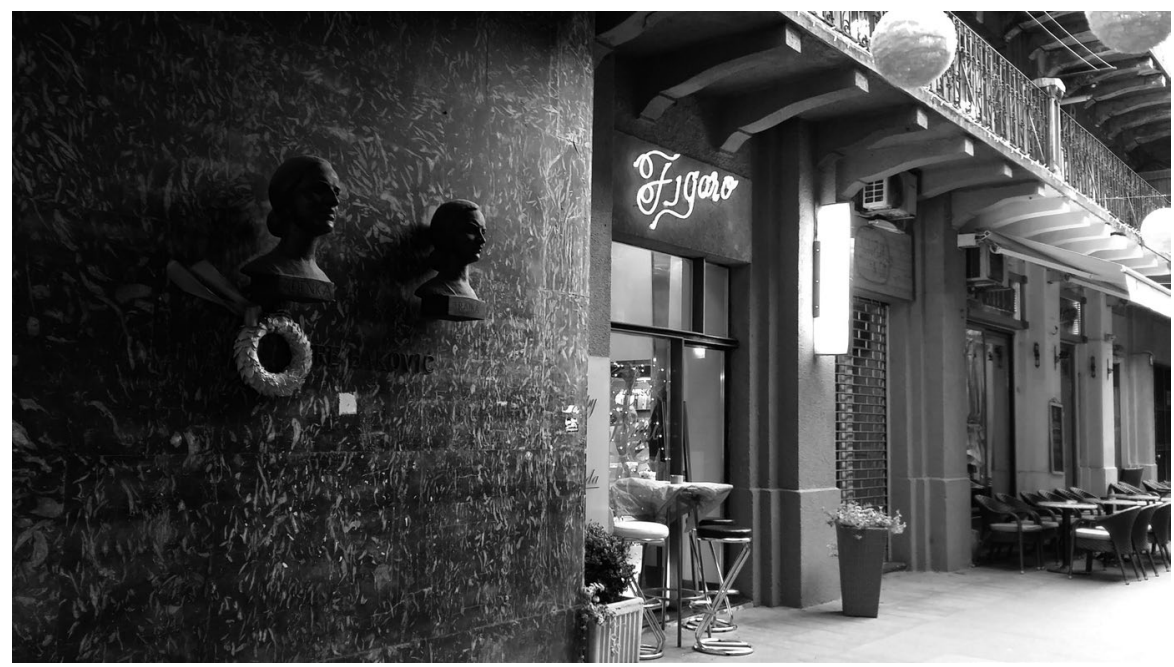

Slika 5: Spomenik sestrama Baković, Zagreb

(Foto: H. Stublić)

\footnotetext{
${ }^{15}$ Navode je moguće provjeriti konzultirajući Opću enciklopediju Jugoslavenskoga leksikografskog zavoda. 1977. Zagreb: Jugoslavenski leksikografski zavod.

${ }^{16}$ Vidi: Kiš i Cigoj 2011 (https://www.jutarnji. hr/kultura/art/stefica-je-miskecu-slomila-srce.-poludioje-poceo-piti-zavrsio-kao-prosjak.-ona-se-udala-za-bogatog-nijemca/3101909/) i Rimac 2009 (https://www.jutarnji.hr/vijesti/zagreb/miskecov-prolaz-ponovno-prolaz-sestara-bakovic/2862623/) (pristup 29. 11. 2019.).
} 
Ovo je jasan primjer kako sjećanje kroz godine slabi, povijesni događaji postanu zaboravljeni, a baština zanemarena ili negirana. Narednih godina sjećanje na sestre Baković pomalo slabi te nestaje iz kolektivnog sjećanja lokalne zajednice i naroda, a nove generacije mladih gotovo uopće nemaju svijest o tome tko su sestre Baković niti koga predstavljaju dvije biste u poznatom zagrebačkom prolazu. Naime, cijela povijest pokreta otpora (i narodnooslobodilačke borbe - NOB) za vrijeme Drugoga svjetskog rata gotovo je u potpunosti izbrisana iz školskih udžbenika povijesti.

Iz ovog razloga godine 2008. poznata hrvatska umjetnica Sanja Iveković osmislila je umjetnički projekt u znak sjećanja na sestre Baković. ${ }^{17} \mathrm{Uz}$ spomen-biste sestara postavila je jednostavnu školsku ploču s dostupnim kredama i jednostavnim naslovnim pitanjem: "Tko su bile sestre Baković?". Bio je to poziv prolaznicima da izraze svoja razmišljanja potaknuta spomenikom i postavljenim pitanjem. S druge pak strane bilo je to i svojevrsno istraživanje mišljenja prolaznika o navedenoj temi. Reakcije su bile raznolike, no mnogi doista nisu znali odgovor na pitanje i nisu se time previše zamarali. Danas prolaz službeno ponovno nosi naziv Prolaz sestara Baković nakon inicijative za preimenovanjem koja je realizirana 2009. godine.

\section{Primjer treći - Busan, Južna Koreja}

Treća priča odličan je primjer kako nemogućnost i nevoljkost da se politički establišment jedne zemlje suoči sa svojom prošlošću i teškom baštinom može rezultirati ozbiljnim i nepredvidljivim posljedicama i utjecati na svakodnevan život. Priča je ponovno vezana uz događaje iz Drugoga svjetskog rata, a mjesto radnje jest grad Busan u Južnoj Koreji. Početkom siječnja 2017. godine brojni su mediji izvještavali o tome kako su Južna Koreja i Japan ušle u ozbiljnu diplomatsku krizu poradi postavljanja jednog spomenika u javnom prostoru u gradu Busanu u Južnoj Koreji (Qiu 2017).

Riječ je, u oblikovnom smislu, o brončanoj skulpturi djevojčice koja sjedi na klupi. Spomenik ne predstavlja jednu konkretnu osobu, nego specifičnu grupu žena i mladih djevojaka, i mnogi slični spomenici nalaze se diljem Južne Koreje i svijeta. ${ }^{18}$ Ipak, u ovom konkretnom primjeru iz Busana ni spomenik ni lokacija nisu slučajni - naime, on se nalazi na javnoj površini točno ispred ulaza u Japansku ambasadu u Busanu. Svi navedeni spomenici postavljeni su u znak sjećanja na tzv. žene za utjehu (engl. comfort woman). Sam izraz učestalo se koristi kod ove i srodnih tema, a zapravo je riječ o eufemizmu koji

\footnotetext{
${ }^{17}$ Vidi: Svilar 2008 (“Tko su bile sestre Baković?”, https://www.booksa.hr/vijesti/sve/tko-su-bilesestre-bakovic) (pristup 29. 11. 2019.).

${ }^{18}$ Spomenici se još nalaze u SAD-u, Australiji, Japanu i Njemačkoj.
} 
označava djevojčice i mlade žene koje su korištene kao seksualne robinje japanskim vojnicima tijekom Drugoga svjetskog rata. Dugi niz godina ova je tema bila negirana i prešućivana među azijskim zemljama, a sam Japan dugo nije priznavao krivnju za počinjeni zločin nad tim ženama.

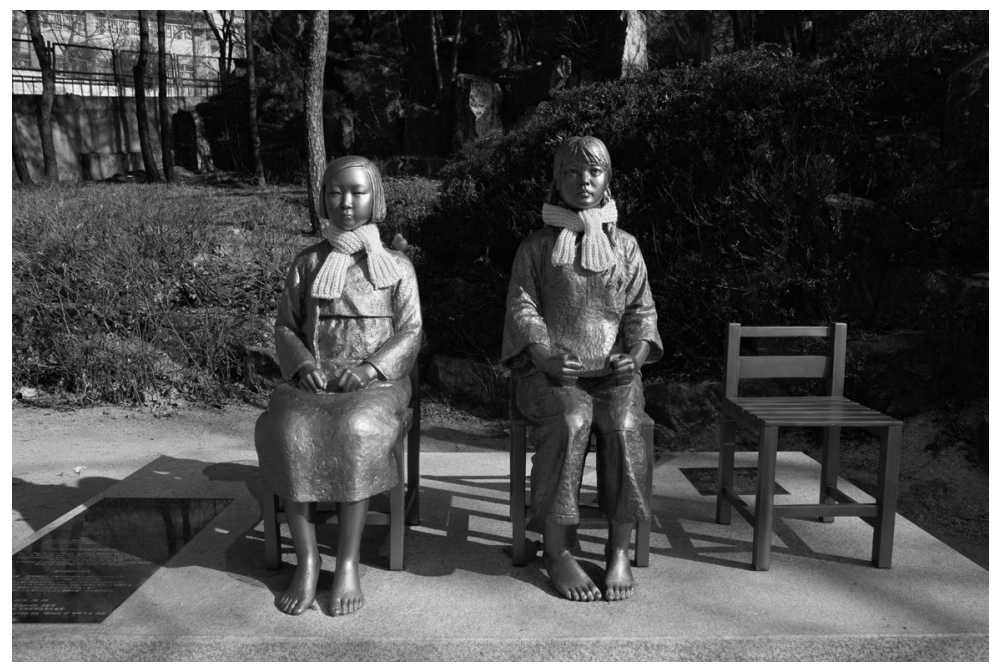

Slika 6: Spomenik ženama za utjehu, Seoul

(Foto: Lisy)

Prema nekim svjedočanstvima i zapisima mnoge su mlade žene kidnapirane i držane kao zatvorenice japanske vojske u vojnim bazama. Mnogim svjedočenjima i sudskim procesima dokazano je da su dosta bile zatvorene u logorima koje nisu smjele napustiti, a tamo su dovođene s jasnom svrhom kako bi služile kao seksualne robinje japanskim vojnicima. Dugo vremena službeni Japan tvrdio je da navedene žene nisu bile zatvorenice, nego prostitutke koje su bile novčano plaćene i slobodne da napuste logore u svakom trenutku. Žene su dovođene protiv svoje volje ponajviše iz Koreje, Kine, Tajvana, Indonezije i nekih drugih država u okruženju.

Situacija se počela mijenjati nakon što je jedna žena, žrtva ovog zločina, odlučila istupiti i tužiti Japan na sudu. Nakon njezina istupa u javnosti počele su se javljati mnoge druge žene žrtve zločina i svjedočiti o strašnim događajima iz vremena rata. Tek nakon što su brojnim istraživanjima i svjedočanstvima dokazi protiv Japana bili neosporni, službeni Japan odlučio je priznati krivnju za ovaj ratni zločin tijekom svoje prošlosti te se javno ispričao zbog događaja. Južnokorejska i japanska vlada potpisale su sporazum kojim se Japan obvezao uplatiti određenu svotu novaca u fondaciju za pomoć ženama žrtvama seksualnog zločina tijekom Drugoga svjetskog rata. Tim činom obje su strane smatrale da je slučaj razriješen, da može biti uklonjen iz javne rasprave i "nestati" iz 
javnog prostora. Ipak, same žrtve nisu se s time slagale..$^{19}$ Više od novca, njima je trebalo priznanje, vidljivost, održavanje sjećanja i poštovanje. U tom smislu pokrenuta je inicijativa za postavljanjem nekoliko desetaka sličnih memorijala žrtvama ovog zločina, a jedan takav jest navedeni spomenik u Busanu ispred Japanske ambasade. Riječ je neminovno o svojevrsnoj provokaciji, ali i podsjetniku da se pitanja teške baštine ne rješavaju samo na "političkom stolu", nego obavezno u suradnji sa zajednicom i stradalima.

\section{NEVOLJE S POJMOM TEŠKA BAŠTINA}

Kao što je iz prethodnih primjera vidljivo, teška baština poprima raznolike oblike. Primjer iz prakse o uspostavi i djelovanju Fondacije Memorijala ubijenim Židovima Europe u Berlinu ilustrira kako ni u Njemačkoj taj proces ne teče glatko te kako je svaki proces memorijalizacije i interpretacije nekog aspekta teške baštine obilježen brojnim greškama i pogrešnim pristupima. Primjer iz Busana govori nam o tome kako svi projekti vezani uz tešku baštinu moraju biti od samog početka temeljeni na suradnji i dijalogu sa zajednicom i odgovarati potrebama zajednice i ljudi koji su tim događajima pogođeni. Projekti koji su oblikovani neovisno od zajednice i samo poradi promicanja političkog establišmenta nemaju općedruštvenu svrhu ni budućnost. Kada baština postane samo instrument politike, otpor u zajednici je neizbježan. Takvo djelovanje nacionalnih vlada čini se kao poza koja ne uvažava stvarne potrebe ljudi. Slojevitost i kompleksnost teške baštine očituje se na primjeru spomenika sestrama Baković u Zagrebu koji u političkom kontekstu raspada Jugoslavije i osamostaljenja Hrvatske poprima sasvim nove interpretacijske razine. Antifašistička borba slavi se svugdje u svijetu i njezina pozicija rijetko se dovodi u pitanje. Ovaj slučaj nas je poučio koliko je baština, ovisno o kontekstu i vremenu, podložna manipulativnim interpretacijama i promjeni njezina značenja.

Zašto tešku baštinu možemo smatrati teškom? Ili drugim riječima rečeno, koje karakteristike neki segment baštine mora imati kako bi bio smatran teškom baštinom? Tešku baštinu definiraju tri aspekta:

1. teška za istraživanje,

2. teška za interpretaciju,

3. teška za prezentaciju/komunikaciju.

Ako promotrimo tri primjera teške baštine navedena u ovom radu - iz Berlina, Zagreba i Busana - vidjet ćemo da sva tri imaju gore navedena obilježja. Oni su teški

\footnotetext{
19 Više o tužbama protiv Japana vidi: SONG, Shin-do. Lawsuits brought against Japan by former Korean "comfort women", https://kls.law.columbia.edu/content/lawsuits-brought-against-japanformer-korean-comfort-women (pristup 14. 7. 2019.).
} 
za istraživanje iz više mogućih razloga. Jedan je svakako nedostupnost arhivske i slične građe koja je nužna kako bi se tema cjelovito obradila. To može biti zato što je građa kroz godine uništena ili izgubljena, ili pak jer je zatvorena i nedostupna istraživačima. Drugi je percepcija teme od strane znanstvene zajednice i društva koje moguće ne žele ili nisu sklone tomu da se o navedenoj temi više istražuje. Sveprisutni diskurs kod tema teške baštine često ide u smjeru obeshrabrivanja znanstvenika i pojedinaca da o temi govore ili je dublje istražuju.

Jednom prikupljena i istražena građa iz domene teške baštine izrazito je teška za interpretiranje. Prikupljeni podaci često su dvosmisleni, višeznačni ili nedorečeni. Neiskusni istraživači koji nemaju jasnu znanstvenu poziciju mogu lako biti navedeni na pogrešan trag ili manipulirani kakofonijom onoga što se istraživanjem teške baštine prikupi. Čak i kod iskusnih istraživača mogu se javiti brojne nedoumice kako pristupiti interpretaciji neke teme koju smatramo teškom. Interpretacija je i u manje složenim slučajevima vrlo zahtjevna aktivnost koja pretpostavlja širok spektar znanja i vještina.

Jednom istražena i interpretirana baština potom treba biti komunicirana nekome - zajednici/publici ili korisniku te baštine. Iz ranije navedenog primjera Busana vidimo kako je odluka o šutnji, tj. nekomuniciranju teške baštine, jedan od lošijih poteza u smislu suočavanja s teškim povijesnim događajima te ne čini ništa dobro za buduće naraštaje. Isto tako, iz berlinskog primjera vidimo da i u slučajevima kada postoji jaka volja da se teška baština komunicira, pa čak i kad je to napravljeno u direktnoj suradnji sa zajednicom koje se ta teška baština tiče, postoji mogućnost da stvar ne bude pozitivno prihvaćena od strane svih.

Do sada su izneseni neki argumenti koji idu u prilog razumijevanju upotrebe pojma teške baštine. No, valjda navesti i protuargumente ovakvoj distinkciji između pojmova baštine i teške baštine te zašto upotreba pojma teške baštine može biti problematična. Baština ne može biti teška jer:

1. nešto ili jest označeno kao baština ili nije baština,

2. sva baština može za nekoga biti teška,

3. pojmovna distinkcija može se zloupotrijebiti.

Neovisno o svom karakteru, neki segment baštine ili postoji kao takav u kolektivnoj svijesti društva ili ne postoji. Distinktivnost pojmova baština i teška baština implicira da je moguće preciznim sustavom kriterija odrediti crtu razgraničenja baštine od teške baštine. S druge pak strane, sasvim je valjan argument da sva baština za nekoga može biti teška, što ovisi o promatraču i poziciji koja se zauzima prilikom evaluacije. Baština kao društveni konstrukt podložan različitim interpretacijama i korišten u raznorodne svrhe oko kojeg ne postoji nužno uvijek društveni konsenzus u svojoj biti jest teška baština. Baština kao pojam označava nešto što je naslijeđeno i dio je identiteta neke zajednice, 
ona može biti prepoznata ili ne mora, ovisno o različitim okolnostima. No, uvođenje distinktivnog pojma teške baštine koji u sebi nosi snažnu negativnu konotaciju otvara prostor da se u ideološkom smislu zloupotrijebi. Sam čin označavanja nekog aspekta baštine - teškom baštinom - može pridonijeti atribuiranju raznih negativnih konotacija i izjednačavanju sa srodnim fenomenima. Kao primjer možemo navesti mnogobrojne antifašističke spomenike i spomenike NOB-a koji su mahom nastali u poslijeratnom razdoblju. Ako ih označimo teškom baštinom socijalizma ili komunizma, nismo li in tim činom značenjski izjednačili s fašističkom ili nacističkom baštinom? U svakom trenutku moramo biti svjesni mogućih snažnih negativnih reperkusija prilikom korištenja pojma teške baštine te njezinih mogućih ideoloških zloupotreba.

Što bismo o ranije navedena tri primjera teške baštine - iz Berlina, Zagreba i Busana - mislili kada bi bili ispričani kao primjeri baštine, a ne u podnaslovu odmah označeni kao teška baština? Označavanjem ovih primjera pojmom teška baština oni su inicijalno neizbježno stavljeni u određeni društveno-politički kontekst, s jasno naglašenom pozicijom s koje se govori. Zauzimanjem te pozicije, implikacije mogu biti dalekosežne. Možemo li o naredna dva baštinska primjera raspravljati na isti način - Nacionalni park Plitvička jezera i Spomen-područje Jasenovac? Možda nam se naoko čini da to ne možemo, no možda bismo trebali? Može li pak brisanje pojmovne razlike zamagliti karakter nekih lokaliteta i baštinskih cjelina? Što bi se dogodilo kada o ustaškom logoru u Jasenovcu ne bismo govorili kao o fenomenu teške baštine, nego samo baštine?

\section{ZAKLJUČAK}

Unatoč brojnim pokušajima teorijskog raščlanjivanja i definiranja kompleksnog pojma baština, on i dalje zahtijeva nove analize i pristupe iz različitog kuta gledanja. Riječ je o procesu koji nikada neće biti dovršen prije svega zbog promjenjive prirode baštine, ako je shvatimo kao proces i produkt ljudskog djelovanja. Kroz desetljeća teorijskog i znanstvenog proučavanja ovog fenomena detektirani su mnogi različiti oblici baštine, a najupečatljiviji preokret (u teorijskom smislu) dogodio se utvrđivanjem i prihvaćanjem nematerijalne baštine kao nečega supstancijalno različitoga od dotada tradicionalno shvaćane materijalne baštine kao jedine relevantne. Ovakav pristup omogućio je propitivanje nematerijalnosti cjelokupne baštine (svaki oblik baštine u svojoj suštini posjeduje neka nematerijalna svojstva), a dalje i do razvoja teorijskog stajališta da baština kao takva uopće ne postoji, nego da je riječ o procesu ili produkciji direktno uvjetovanoj ljudskim svjesnim i nesvjesnim djelovanjem.

Analizom dostupne literature i korištenja pojma teške baštine (te ostalih srodnih pojmova) uočljiva je njegova neadekvatnost. lako možda ispravno adresira karakter 
ovoga specifičnog oblika baštine koji je svojom kompleksnošću težak za interpretaciju i brigu, i dalje nosi relativno negativan predznak kao nešto što je manje poželjno od ostatka baštine koji taj predznak ne nosi. I dok je u teoriji situacija poprilično jasna, u praksi je vidljivo da je mogućnost da ijedna društvena zajednica zauzme progresivan stav prema svojoj teškoj baštini izrazito mala. U većini slučajeva poticanje na preispitivanje prošlosti te identiteta i vrijednosti koji iz nje proizlaze često završavaju ozbiljnim prijeporima i sukobima. Pojam teške baštine stoga treba koristiti oprezno i s distancom.

S druge pak strane, prilika je to da se progovori o svim "neugodnim" temama i tabuima. Neupitna je činjenica da napretka društva nema bez suočavanja sa svakim aspektom teške baštine, prepoznavanjem takvih mjesta i ljudi kojih se to tiče te da se stvarna snaga nekog društva očituje u njegovoj sposobnosti da budu iskreni prema sebi i drugima te da djeluju tako da se svaka greška, neovisno o tome koliko velika, ipak ispravi i da istina i pravda budu zadovoljene. Za stanje i status teške baštine odgovorni su svi, tiče se svih i briga je društva u cjelini. Naša je profesionalna i ljudska dužnost da pristupimo ovim temama i baštini s punom pažnjom i uvjerenjem da baština u svakom svom obliku posjeduje transformativnu snagu koja samo čeka da bude oslobođena.

\section{LITERATURA}

ACHS. 2012. Critical heritage studies - Manifesto. http://www.criticalheritagestudies.org/ history/ (pristup 14. 8. 2019.)

ASHWORTH, Gregory i TUNBRIDGE, John. 1996. Dissonant Heritage: The Management of the Past as a Resource in Conflict. New York: J. Wiley.

CHOAY, Françoise. 2001. The Invention of the Historic Monument. Cambridge: Cambridge University Press.

COLLINS DICTIONARY. https://www.collinsdictionary.com/ (pristup 14. 8. 2019.)

COMFORT WOMEN MONUMENTS. http://peace.maripo.com/p_comfort_women.htm (pristup 14. 8. 2019.)

DESVALLÉES, André i MAIRESSE, François, ur. 2010. Concepts clés de muséologie. https://docplayer.fr/418869-Concepts-cles-de-museo-lo-gie.html (pristup 14. 8. 2019.)

DESVALLÉES, André i MAIRESSE, François, ur. 2010. Key Concepts of Museology. ICOM International Committee for Museology (ICOFOM). Paris: Armand Colin.

DUDEN. https://www.duden.de/ (pristup 14. 8. 2019.)

HARRISON, Rodney. 2013. Heritage: Critical Approaches. London: Routledge. HRVATSKI JEZIČNI PORTAL. http://hjp.znanje.hr/ (pristup 14. 8. 2019.)

HUSE, Norbert. 1997. Unbequeme Baudenkmale: Entsorgen? Schützen? Pflegen? München: C. H. Beck. 
ICCROM. 1990. Definition of cultural heritage - references to documents in history.

Ur. J. Jokilehto. http://cif.icomos.org/pdf_docs/Documents\%20on\%20line/ Heritage\%20definitions.pdf (pristup 14. 8. 2019.)

KIŠ, Particia i CIGOJ, Mark. 2011. "Štefica je Miškecu slomila srce. Poludio je, počeo piti, završio kao prosjak. Ona se udala za bogatog Nijemca". Jutarnji list, 2. 2. 2011. https://www.jutarnji.hr/kultura/art/stefica-je-miskecu-slomila-srce.-poludio-jepoceo-piti-zavrsio-kao-prosjak.-ona-se-udala-za-bogatog-nijemca/3101909/ (pristup 29. 11. 2019.)

LAROUSSE. http://www.larousse.fr/ (pristup 14. 8. 2019.)

LOGAN, William i REEVES, Keir, ur. 2009. Places of Pain and Shame: Dealing with 'Difficult Heritage'. London: Routledge

MACDONALD, Sharon. 2006. "Undesirable Heritage: Fascist Material Culture and Historical Consciousness in Nuremberg". International Journal of Heritage Studies, vol. 12:1:9-28. DOI: https://doi.org/10.1080/13527250500384464

MACDONALD, Sharon. 2009. Difficult Heritage: Negotiating the Nazi Past in Nuremberg and Beyond. London: Routledge.

MACDONALD, Sharon. 2009. "Unsettling memories: Intervention and controversy over difficult public heritage". U Heritage and identity: Engagement and demission in the contemporary world, ur. Marta Anico i Elsa Peralta. London: Routledge, 93-104.

MACDONALD, Sharon. 2015. "Is 'Difficult Heritage' Still 'Difficult'?: Why Public Acknowledgment of Past Perpetration May No Longer Be So Unsettling to Collective Identities". Museum International, vol. 67:6-22.

DOI: https://doi.org/10.1111/muse.12078

MERRIAM-WEBSTER DICTIONARIES. https://www.merriam-webster.com/dictionary/ (pristup 14. 8. 2019.)

NORA, Pierre. 1989. "Between Memory and History: Les Lieux de Mémoire". Representations, vol. 26:7-24. DOI: https://doi.org/10.2307/2928520

RIMAC, Ivana. 2009. "Miškecov prolaz ponovno Prolaz sestara Baković?". Jutarnji list, 7. 9 . 2009. https://www.jutarnji.hr/vijesti/zagreb/miskecov-prolaz-ponovnoprolaz-sestara-bakovic/2862623/ (pristup 29. 11. 2019.)

SMITH, Laurajane. 2006. Uses of Heritage. London - New York: Routledge.

SONG, Shin-do. [s. a.]. Lawsuits brought against Japan by former Korean "comfort women". https://kls.law.columbia.edu/content/lawsuits-brought-against-japanformer-korean-comfort-women (pristup 14. 08. 2019.)

STUBLIĆ, Helena. 2018. "A museum object, sacred, yet fragile - a lesson of the Croatian museum transition". U Museology and the Sacred - Papers from the ICOFOM 41th symposium held in Tehran (Iran), 15-19 October 2018., ur. François Mairesse. Paris: ICOFOM, 203-207.

SVILAR, Neven. 2008. "Tko su bile sestre Baković?". Booksa.hr. https://www.booksa.hr/ vijesti/sve/tko-su-bile-sestre-bakovic (pristup 29. 11. 2019.) 
OPĆA ENCIKLOPEDIJA JUGOSLAVENSKOG LEKSIKOGRAFSKOG ZAVODA. 1977.

Zagreb: Jugoslavenski leksikografski zavod.

OXFORD DICTIONARIES. https://en.oxforddictionaries.com/definition/heritage

(pristup 14. 8. 2019.)

QIU, Peipei. 2017. Why Korea's 'Comfort Women' must be remembered.

http://www.scmp.com/week-asia/opinion/article/2061990/why-koreas-comfortwomen-must-be-remembered (pristup 14. 8. 2019.)

STIFTUNG DENKMAL FÜR DIE ERMORDETEN JUDEN EUROPAS.

https://www.stiftung-denkmal.de/startseite.html (pristup 14. 8. 2019.)

UNESCO. 1989. Draft Medium Term Plan 1990-1995, 25 C/4. http://unesdoc.unesco.org/ images/0008/000825/082539eb.pdf (pristup 14. 8. 2019.).

UNESCO. 2003. Convention for the Safeguarding of the Intangible Cultural Heritage.

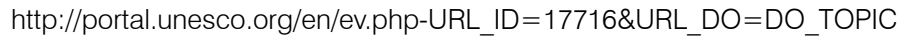

\&URL_SECTION=201.html (pristup 29. 11. 2019.)

\section{The Face and Backdrop of a Heritage: A Contribution to the Debate on the Concept of Difficult Heritage}

\section{Helena Stublić}

This paper provides insight into the issues of concepts of heritage and difficult heritage. A deeper exploration of the sources and use of these concepts is for the purpose of illuminating the positions that occupy their use and the repercussion arising therefrom. The difficult heritage is a concept which is mostly used to mark heritage phenomena that are in conflict with official narratives and cultural policies. The paper presents three examples of difficult heritage - from Berlin, Zagreb and Busan - which will serve as a basis for analyzing this concepts. The paper will show the justification for the use of the distinctive concept of difficult heritage and what its strengths and weaknesses are when used within scientific discourse.

Keywords: heritage, difficult heritage, interpretation, authorised heritage discourse, musealisation paradox, museology, nazism, anti-fascism

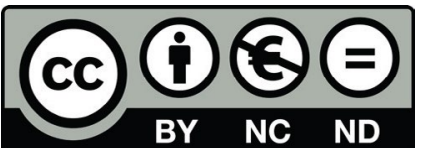

Articles published in this journal are Open Access and can be distributed under the terms and conditions of the Creative Commons license Attribution-NonCommercial-NoDerivatives 4.0 (http://creativecommons.org/licenses/by-nc-nd/4.0/) 